\title{
Performance of sweet cherry cultivars grafted on Colt rootstock
}

\author{
Csihon Á., Bicskei D. K., Dremák P., \& Gonda I. \\ University of Debrecen, Faculty of the Agricultural and Food Sciences and Environmental Management, Institute of Horticulture \\ 138. Böszörményi str., Debrecen, H-4032, Hungary, author for correspondence: Csihon, Á. (csihonadam@agr.unideb.hu)
}

\begin{abstract}
Summary: In this paper growing characteristics and fruit bearing parameters of 'Lapins', 'Kordia', 'Sweetheart' and 'Regina' sweet cherry cultivars grafted on vigorous Colt rootstock were evaluated at the University of Debrecen, Pallag Experimental Station. Based on our data five years old trees can be described with homogenous strong growing, but very week yielding (2.1-3.1 kg/tree), as while fruit size varies between 26.2 and $27.2 \mathrm{~mm}$. Producing the examined cultivars on Colt rootstock with high plant density requires higher attention and more interventions (root pruning, sawing the trunk) during the technology.
\end{abstract}

Csihon Á., Bicskei D. K., Dremák P., Gonda I. (2018): Performance of sweet cherry cultivars grafted on Colt rootstock. International Journal of Horticultural Science (1-2): 7-10. https://doi.org/10.31421/IJHS/24/1-2./1540

Key words: sweet cherry, Colt rootstock, cultivars, vegetative characteristics, generative accomplishment

\section{Introduction}

In the last years profitability of more fruit species has decreased significantly, which resulted that attention of producers turned to the fruits with higher profitability. In Europe sweet cherry and apricot with high quality can be sold almost unlimited ensuring decent income for the farmers (Szabó, 2010).

Researches about sweet cherry production focus on the intensity growing all over the world, namely the realization of producing with small trees which ensure high quality and quantity (Gonda, 2012; Holb, 2006; Holb et al., 2011). One condition of planting intensive sweet cherry orchard is the application of dwarfing rootstock (Simon et al., 2004; Blake \& Balmer, 2005; Cantín et al., 2010; Lanauskas et al., 2012), although different opinions also exist. Zahn (1996) suggested establishing intensive orchard both with vigorous and dwarfing rootstocks. According to Hrotkó et al. (2009) producing sweet cherry with intensive technology is also possible on vigorous rootstocks, but its condition that the time of turning to bearing must be early. Based on Vaszily \& Gonda (2010) researches planting orchard with high density on Prunus mahaleb rootstock is achievable, nevertheless special pruning policy recommended for each cultivar to maintain high yield and fruit quality for a longer period. Szabó et al. (2011a) also confirmed this state proving that intensive growing technology can be performed also on growth inducing rootstocks, but dwarfing rootstocks (PHL-A, Gisela 6) can provide earlier cropping and adequate fruit size at the same time.

Success of the production is basically determined by the applied cultivar through the quality parameters of the fruits. For now the large heart-shaped but soft, light and black colored cultivars are completely excluded from the fresh market. Main requirements of the cultivars are the next: dark red color, at least $28 \mathrm{~mm}$ fruit size, high firmness, homogenous size and color, suitability for shipping, storage and sorting (Szabó et al.,
2011). Expectations against the fruits weight also changed in the last years, as preferred value increased from 6-8 $\mathrm{g}$ to $9-12 \mathrm{~g}$ (Apostol, 1999; Waterman, 2005; Thurzó et al., 2006, 2008).

Based on the quantity and quality of the home sweet cherry cultivars the results of the domestic breeding are acknowledged also at European and world level. In the NÉBIH's National List of Varieties currently 21 domestic sweet cherry cultivars are listed, and more candidates are waiting for the registration (NÉBIH, 2016). From them more are recommended to plant also in the largest European cherry producer country, in Italy (Palasciano, 2013). However expanding our cultivar assortment requires also the testing and planting of new foreign cultivars with early or late ripening time, self-fertile ability, large fruit size and high firmness (Szabó et al., 2011).

\section{Materials and methods}

Location of the examinations is placed at the University of Debrecen, Pallag Experimental Station. The aim of this study was to evaluate the growing characteristics and fruit bearing parameters of sweet cherry cultivars grafted on vigorous rootstock.

Table 1. Ecological parameters of the experimental site

\begin{tabular}{|l|l|}
\hline Mean temperature of the year & $10-11^{\circ} \mathrm{C}$ \\
\hline Sunshine hours & $1900-2050$ \\
\hline Precipitation & $530 \mathrm{~mm}$ \\
\hline $\mathrm{pH}$ of the soil & $\mathrm{pH} 6.5$ \\
\hline Humus content & $0.8-1.0 \%$, light sandy loam \\
\hline "Arany" number of heaviness & $25-27$ \\
\hline
\end{tabular}


The experimental orchard was established in spring of 2013. Planting material was one year old scion. Trees were trained to slender spindle canopy. Spacing distance is $5 \mathrm{~m} \mathrm{x} 2 \mathrm{~m}$. Applied cultivars are 'Lapins', 'Sweetheart', 'Regina' and 'Kordia', which were grafted on Colt rootstock with very strong vigor.

The orchard follows the integrated fruit production guidelines. Trees are watered with dropping irrigation system. Pruning is performed once in a year, at the end of winter.

Our work focuses on the assessment of the fruit bearing and fruit quality parameters but the growing characteristics of the trees were also evaluated in details, which determine basically the training and maintaining of the canopy. Each variant of rootstock $x$ cultivar was represented by five trees, which were in randomized block design. Growing peculiarities were measured in autumn of 2017, after leaf fall. Statistics were performed by ANOVA at $\mathrm{P}=0.05$ level using LSD test.

\section{Examined sweet cherry rootstock}

Colt (Prunus avium $\times$ Prunus pseudocerasus): hybrid of the Prunus avium with very strong vigor. Compatible with the cherry cultivars, time of turning to bearing is early, trees have a long life period. It tolerates well the high soil moisture, not sensitive to the root drowning, but it does not favor the dry soils.

\section{Examined sweet cherry rootstocks}

'Lapins': self-pollinating cultivar comes from Canada. Fruit size is large $(28 \mathrm{~mm})$, globular, well-looking. It has high firmness, but it is sensible to cracking, and has less intensive aroma. Harvest period is in mid-season. Time of turning to bearing is late, but after that trees bear regularly and abundantly. Vigor of the trees is middle strong which have bad ramification ability.

Sweet Heart': self-pollinating cultivar comes from Canada. Fruits have medium size $(>25 \mathrm{~mm})$, bright red color and round shape. Taste is sweet and slightly aromatic. Ripening time is late. Cropping is very heavy and precocious. Tree habit is spreading with few branches.

'Regina': self-fertile cultivar comes from Germany. Fruit is large ( $>28 \mathrm{~mm})$, firm with low-acid and sweet flavor, skin is dark. Rain crack resistance is very high. Late season cultivar. Stem is very long. Productivity is medium. Vigor of the tree is strong with good ramification.

'Kordia': self-fertile cultivar comes from Czech Republic. Harvest period is in mid season. Fruit is dark red with large size $(>27$ $\mathrm{mm}$ ) and good flavor. Shape is long heart, flesh is firm. Fruits have tolerance to fruit splitting. Stem is long. It has medium productivity and strong vigor.

\section{Results and discussion}

Trunk thickness is expressed in trunk cross sectional area (TCSA), which can be named as a complex index of the vegetative accomplishment (Table 2). Significant differences is not seen among the data of five years old trees. 'Lapins' and 'Kordia' reached the highest trunk thickness $\left(136 \mathrm{~cm}^{2}\right)$, as
'Regina' presented 5.1\% lower values $\left(129.5 \mathrm{~cm}^{2}\right)$. Lowest TCSA was measured with 'Sweetheart' $\left(119.5 \mathrm{~cm}^{2}\right)$.

Tree height varies between 4.6 and $5.0 \mathrm{~m}$, as trees have the necessary cropping surface to produce high yields, moreover height can be considered slightly excessive.

Ratio of the trunk thickness and the basic scaffold branches (Zahn-index) is used to describe the growing balance of the trees. All cultivars displayed higher indexes than the optimal 0.5 value, which means that the main basal branches tend to overthicken.

Table 2. Parameters related with tree size of five years old trees (Debrecen - Pallag, 2017)

\begin{tabular}{|l|c|c|c|}
\hline & TCSA $\left(\mathrm{cm}^{2}\right)$ & $\begin{array}{c}\text { Tree height } \\
(\mathrm{cm})\end{array}$ & Zahn-index \\
\hline 'Lapins' & 136.1 & 477 & 0.83 \\
\hline 'Sweetheart' & 119.5 & 463 & 0.72 \\
\hline 'Regina' & 129.5 & 477 & 0.74 \\
\hline 'Kordia' & 136.2 & 497 & 0.68 \\
\hline LSD $5 \%$ & 38.8 & 60 & 0.08 \\
\hline
\end{tabular}

Table 3. Generative achievement of the examined sweet cherry cultivars (Debrecen - Pallag, 2017)

\begin{tabular}{|l|c|c|c|c|c|c|}
\hline & $\begin{array}{c}\text { Fruit } \\
\text { setting } \\
(\%)\end{array}$ & $\begin{array}{c}\text { Yield } \\
(\mathrm{kg} / \\
\text { tree })\end{array}$ & $\begin{array}{c}\text { Yield/ } \\
\text { TCSA } \\
\left(\mathrm{g} / \mathrm{cm}^{2}\right)\end{array}$ & $\begin{array}{c}\text { Fruit } \\
\text { size } \\
(\mathrm{mm}) *\end{array}$ & $\begin{array}{c}\text { Fruit } \\
\text { weight } \\
(\mathrm{g})^{*}\end{array}$ & BRIX\%* \\
\hline 'Lapins' & 18.3 & 2.7 & 20.4 & 27.2 & 10.1 & 17.7 \\
\hline 'Sweetheart' & 10.4 & 2.1 & 17.3 & 26.2 & 9.3 & 18.2 \\
\hline 'Regina' & 5.4 & 2.2 & 16.5 & 26.6 & 9.6 & 18.2 \\
\hline 'Kordia' & 4.1 & 3.1 & 23.8 & 26.6 & 10.1 & 17.8 \\
\hline LSD5\% & 5.1 & 2.5 & 21.5 & - & - & - \\
\hline
\end{tabular}

*based on 100 fruits

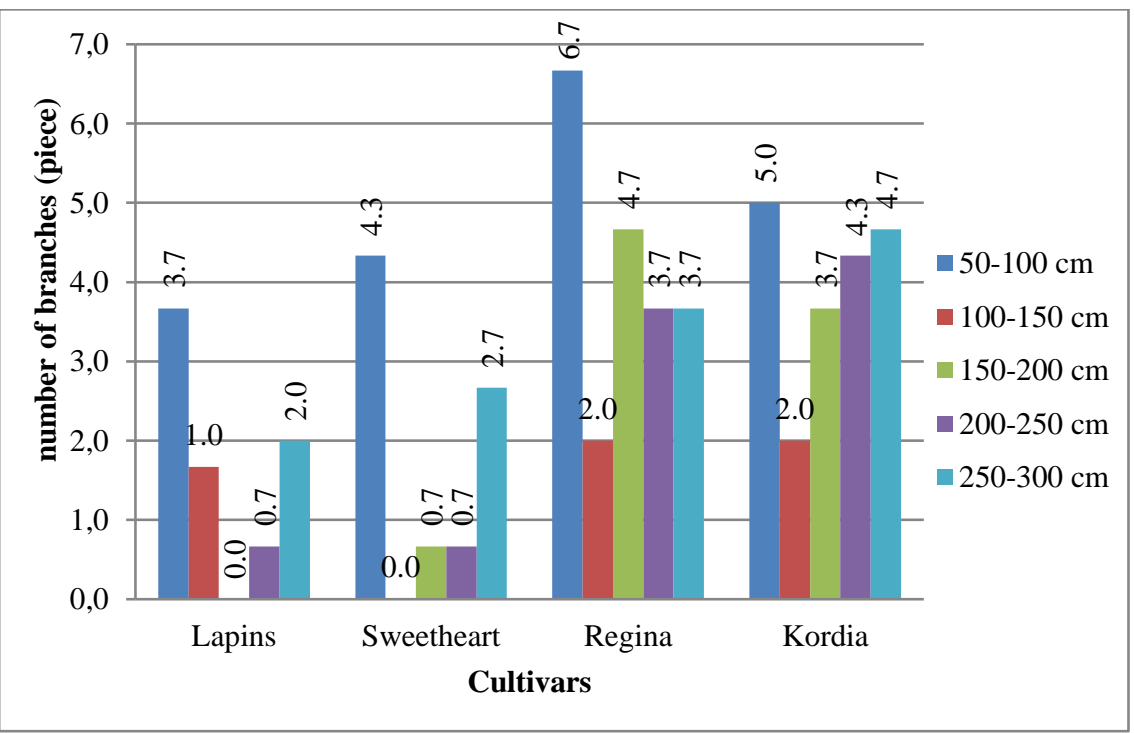

Figure 1. Number of the branches emerging from the central axis in different height zones (Debrecen - Pallag, 2017)

Parameters concerning fruit bearing and fruit quality are concluded in Table 3. Examined cultivars showed very week generative performance on the five years old trees with Colt rootstock. Although fruit setting showed significant differences 


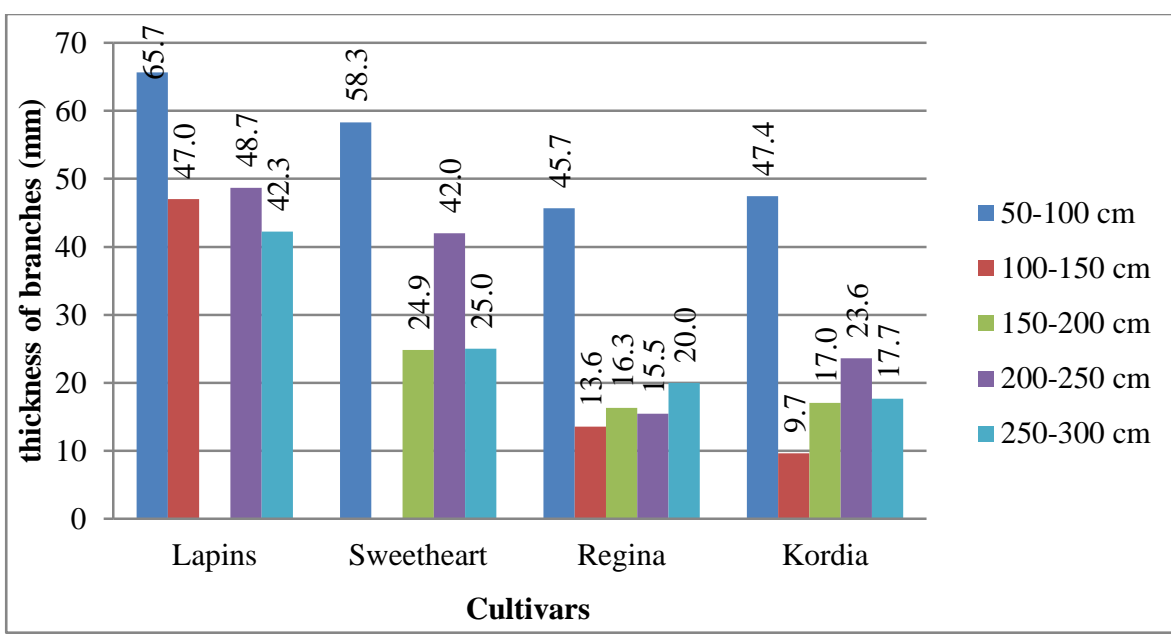

Figure 2. Thickness of the branches emerging from the central axis in different height zones (Debrecen - Pallag, 2017)

Table 4: Number of bouquets of spurs in the central axis in different height zones (Debrecen - Pallag, 2017)

\begin{tabular}{|l|c|c|c|c|}
\hline & $100-150 \mathrm{~cm}$ & $150-200 \mathrm{~cm}$ & $200-250 \mathrm{~cm}$ & $250-300 \mathrm{~cm}$ \\
\hline 'Lapins' & 1.3 & 2.3 & 1.3 & 0.7 \\
\hline 'Sweetheart' & 0.7 & 2.3 & 1.0 & 4.7 \\
\hline 'Regina' & 0.0 & 0.3 & 0.7 & 0.3 \\
\hline 'Kordia' & 0.3 & 1.3 & 0.0 & 1.3 \\
\hline
\end{tabular}

Table 5. Number of bouquets of spurs on the branches with different age (Debrecen - Pallag, 2017)

\begin{tabular}{|l|c|c|c|}
\hline & $\begin{array}{c}\text { On two years old } \\
\text { branches (pieces/m) }\end{array}$ & $\begin{array}{c}\text { On three years old } \\
\text { branches (pieces/m) }\end{array}$ & $\begin{array}{c}\text { On four years old } \\
\text { branches (pieces/m) }\end{array}$ \\
\hline 'Lapins' & 18.5 & 17.4 & 8.1 \\
\hline 'Sweetheart' & 22.8 & 18.8 & 12.4 \\
\hline 'Regina' & 18.0 & 9.9 & 4.5 \\
\hline 'Kordia' & 18.3 & 18.1 & 10.4 \\
\hline
\end{tabular}

Table 6. Fruit bearing parts of the basal scaffold branches (Debrecen - Pallag, 2017)

\begin{tabular}{|l|c|c|c|c|}
\hline & $\begin{array}{c}\text { Number of } \\
\text { bouquets of } \\
\text { spurs/BCSA } \\
\left(\text { pieces/ } / \mathrm{cm}^{2}\right)\end{array}$ & $\begin{array}{c}\text { Number of shoots/ } \\
\text { BCSA } \\
\left(\text { pieces/ } / \mathrm{cm}^{2}\right)\end{array}$ & $\begin{array}{c}\text { Sum of shoots } \\
\text { length/BCSA } \\
\left(\mathrm{cm} / \mathrm{cm}^{2}\right)\end{array}$ & $\begin{array}{c}\text { Length of } \\
\text { shoots }(\mathrm{cm})\end{array}$ \\
\hline 'Lapins' & 3.99 & 1.15 & 69.5 & 59 \\
\hline 'Sweetheart' & 3.83 & 0.92 & 57.7 & 65 \\
\hline 'Regina' & 3.06 & 1.18 & 55.5 & 46 \\
\hline 'Kordia' & 13.11 & 1.27 & 43.4 & 34 \\
\hline
\end{tabular}

Table 7. Parameters of the shoots (Debrecen - Pallag, 2017)

\begin{tabular}{|l|c|c|c|c|c|c|}
\hline & $\begin{array}{c}\text { Bottom } \\
\text { thickness } \\
(\mathrm{mm})\end{array}$ & $\begin{array}{c}\text { Middle } \\
\text { thickness } \\
(\mathrm{mm})\end{array}$ & $\begin{array}{c}\text { Upper } \\
\text { thickness } \\
(\mathrm{mm})\end{array}$ & $\begin{array}{c}\text { Average } \\
\text { thickness } \\
(\mathrm{mm})\end{array}$ & $\begin{array}{c}\text { Volume } \\
\text { of shoots } \\
\left(\mathrm{cm}^{3}\right)\end{array}$ & $\begin{array}{c}\text { Number of } \\
\text { buds/ } \\
\text { shoots } \\
(\text { pieces/m) }\end{array}$ \\
\hline 'Lapins' & 8.6 & 6.4 & 4.6 & 6.5 & 19.8 & 34.2 \\
\hline 'Sweetheart' & 8.2 & 6.2 & 4.8 & 6.4 & 21.0 & 41.0 \\
\hline 'Regina' & 5.7 & 4.4 & 3.3 & 4.5 & 7.3 & 34.0 \\
\hline 'Kordia' & 5.0 & 3.9 & 3.3 & 4.1 & 4.5 & 40.5 \\
\hline
\end{tabular}

among the cultivars, harvested yields were near the same. Values of fruit setting were between 4.1 and $18.3 \%$. 'Lapins' presented the highest fruit setting $(18.3 \%)$, as in the case of 'Regina' and 'Kordia' 4.1-5.4\% of the flowers became fruits.

Picked fruit amount was very low with all cultivars $\left(2.1-3.1 \mathrm{~kg} /\right.$ tree; $\left.16.5-23.8 \mathrm{~g} / \mathrm{cm}^{2}\right)$, provable differences are not found. 'Kordia' reached the highest yield $(3.1 \mathrm{~kg} /$ tree $)$, while 'Sweetheart' and 'Regina' displayed the lowest amount (2.1-2.2 kg/tree). Fruit size reached the minimum criteria with each cultivars, as values range up 26.2 to 27.2 $\mathrm{mm}$. Large differences are not recorded neither in fruit weight. 'Sweetheart' and 'Regina' reached 9.3-9.6 g, while 'Lapins' and 'Kordia' showed 10.1 g. Cultivars with lower yield ('Sweetheart' and 'Regina') had higher water soluble dry matter content (18.2 BRIX\%), as cultivars with higher yields ('Kordia' and 'Lapins') showed lower values (17.7-17.8 BRIX\%).

Number of branches were counted emerging from the central axis in different height regions (Figure 1). Lower number of branches were found with 'Lapins' and 'Sweetheart' cultivar (0.0-4.3 pieces), as 'Regina' and 'Kordia' had higher density of ramifies (2.0-6.7 pieces) on the central leader. The weakest ramification ability was observed in the region of $100-150 \mathrm{~cm}$ with 'Sweetheart', 'Regina' and 'Kordia', directly above the basal scaffold branches.

Regarding the thickness of the branches of central leader (Figure 2) it is seen, that the main basal branches are much thicker (45.7$65.7 \mathrm{~mm}$ ), than the above located ones (9.7$48.7 \mathrm{~mm})$. 'Lapins' cultivar means exception from this, as its branches tend to be excessive thick in the upper region of the axis. 'Sweetheart' and 'Kordia' cultivar showed stronger branches in the $200-250 \mathrm{~cm}$ height zones.

Number of bouquets of spurs formed on the central axis is an important parameter regarding the available yields and fruit quality (Table 4), as in the vicinity of the main transport tissues well developed fruits can be picked. Higher density of bouquets of spurs was observed with 'Lapins' (0.7-2.3 pieces) and 'Sweetheart' (0.7-4.7 pieces), as 'Regina' (0.0-0.7) and 'Kordia' (0.0-1.3) presented lower values.

Density of bouquets of spurs of 2-4 years old branches is concluded in Table 5. On the two years old branches 'Sweetheart' showed the highest number of fruit bearing parts (22.8 pieces/m), as 'Kordia', 'Regina' and 'Sweetheart' reached 18.0-18.5 pieces $/ \mathrm{m}$. On three years old parts of the tree values 'Lapins', 'Sweetheart' and 'Kordia' are close to equal (17.4-18.8 pieces/m), while 'Regina' showed lower value (9.9 pieces $/ \mathrm{m})$. 
On four years old branches 'Kordia' and 'Sweetheart' displayed higher density of cropping parts (10.4-12.4 pieces/m), as less bouquets of spurs was counted for 'Regina' and 'Lapins' (4.5$8.1 \mathrm{pieces} / \mathrm{m})$.

Parameters of fruit bearing parts are detailed in Table 6. Number of bouquets of spurs calculated to the branch cross sectional area shows that 'Lapins', 'Sweetheart' and 'Kordia' reached similar values (3.06-3.99 pieces $\left./ \mathrm{cm}^{2}\right)$. 'Kordia' developed much more bouquets of spurs $\left(13.11\right.$ pieces $\left./ \mathrm{cm}^{2}\right)$ due to its better ramification ability, as the main scaffold branches had more secondary twigs than the other cultivars.

'Kordia' can be described with higher number of shoots $\left(1.27\right.$ pieces $\left./ \mathrm{cm}^{2}\right)$, as their average length $(34 \mathrm{~cm})$ and total length $\left(43.4 \mathrm{~cm} / \mathrm{cm}^{2}\right)$ was the lowest. 'Sweetheart' developed the longest shoots $(65 \mathrm{~cm})$ and reached the lowest shoot number $\left(0.92\right.$ pieces $\left./ \mathrm{cm}^{2}\right)$.

Thickness and volume of the shoots showed notable differences (Table 7). Higher average thickness (6.4-6.5 mm) and volume $\left(19.8-21.0 \mathrm{~cm}^{3}\right)$ were measured with 'Lapins' and 'Sweetheart', while 'Regina' and 'Kordia' presented much lower values (4.1-4.5 $\mathrm{mm}$ average thickness, 4.5-7.3 $\mathrm{cm}^{3}$ volume). Accordingly 'Lapins' and 'Sweetheart' developed fewer numbers of long and thick shoots, as 'Regina' and 'Kordia' presented higher number of shorter and thinner shoots.

\section{Conclusions}

Based on our measurements we can conclude that significant differences are not found in the tree size of the examined cultivars ('Lapins', 'Kordia', 'Sweetheart', 'Regina'). Five years old trees grafted on vigorous Colt rootstock can be described with homogenous strong growing, but very week yielding. Harvested fruit amount was very low with all cultivars (2.1-3.1 kg/tree), while fruit size ranged up 26.2 to $27.2 \mathrm{~mm}$. 'Kordia' had the best ramification ability, as developed higher number of branches and bouquets of spurs. 'Lapins' and 'Sweetheart' presented worse ramification ability by improving fewer number of long and thick shoots. Bending down the branches or cutting back the shoots have higher role with these cultivars in the period of the canopy training.

Eventually it can be stated that producing the examined cultivars on vigorous Colt rootstock with high plant density under the ecological conditions of the experimental site requires higher attention and more intervention during the technology. Reaching the early yielding is essential to train small sized trees. Pruning and other fitotechnical interventions (root pruning, sawing the trunk) must serve reducing the vigor of the trees.

\section{Acknowledgements}

\section{覀}

Supported BY the ÚNKP-17-4 New National Excellence Program of the Ministry of Human Capacities" The research/thesis/dissertation is supported by the EFOP 3.6.1-162016-00022 project. The project is co-financed by the European Union and the European Social Fund.

\section{References}

Apostol, J. (1999): Results of the sweet cherry breading programme in Hungary. Acta Hortic. 484: 177-18.

Balmer, M., Blanke, M. M. (2005): Developments in high density cherries in Germany. Acta Hortic. 667:273-277.

Cantín C. M., Pinochet, J., Gogorcena, Y., Moreno, M. A. (2010): Growth, yield and fruit quality of 'Van' and 'Stark
Hardy Giant' sweet cherry cultivars as influenced by grafting on different rootstocks. Sci. Hortic. 123. 329-335. p.

Gonda, I. (2012): Intenzív cseresznye művelési rendszerek itthon és a nagyvilágban. DE AGTC MÉK Kertészettudományi Intézet, Gonda István Bt. 117 p.

Hrotkó, K., Magyar, L., Hoffman, S., Gyeviki, M. (2009): Rootstock evaluation in intensive sweet cherry (Prunus avium L.) orchard. Internat. J. Hortic. Sci. 15(3): 7-12. p.

Holb I J, Vámos A, Lakatos P, Gáll J M, Abonyi F (2011): Some aspects of reduced disease management against Blumeriella jaapii in sour cherry production. Internat. J. Hortic. Sci. 17(1-2): 49-52.

Holb, I. J. (2006): Possibilities of brown rot management in organic stone fruit production in Hungary. Internat. J. Hortic. Sci. 12(3): 87-92.

Lanauskas, J., Uselis, N., Kviklys, D., Kviklienė, N., Buskienè, L. (2012): Rootstock effect on the performance of sweet cherry cv. Lapins. Hortic. Sci. 39. 55-60.

NÉBIH (2016): Nemzeti Fajtajegyzék 2016. Szőlő - Gyümölcs. ISSN 1585-8308. 43. p.

Palasciano, M., Lipari, E., Bassi, G., Giongo, L., Liverani, A., Sirri, S., Lugli, S., Grandi, M., Pennone, F., Scarpato, A., Sartori, A. (2013): Liste varietali 2013: Ciliegio. Terra e Vita 38. Supplemento Liste Varietali: 12-19. p.

Simon, G., Hrotkó, K., Magyar, L. (2004): Fruit quality of sweet cehrry cultivars grafted on four different rootstocks. Internat. J. Hortic. Sci. 10(3): 59-62.

Szabó, Z. (2010): Tendenciák a világ cseresznyetermesztésében. Zöldség-Gyümölcs Piac és Technológia. 2010/június. 13-14. p.

Szabó, Z., Soltész, M., Apáti, F., Nyéki, J. (2010): Conditions and outlooks of growing stone fruits. Internat. J. Hortic. Sci. 16(1): 91-98..

Szabó, Z., Farkas, E., Soltész, M., Fieszl, Cs., Balázs, G., Nyéki, J. (2011a): New sweet cherry cultivars in intensive plantings. Internat. J. Hortic. Sci. 17(1-2): 13-16.

Szabó, Z., Balmer, M., Fieszl, Cs., Farkas, E. (2011b): Fajtahasználat. In.: Intenzív cseresznyetermesztés. Szerk.: Nyéki, J., Soltész, M., Szabó, Z. Debreceni Egyetem, 7-30. p.

Thurzó, S., Drén, G., Dani, M., Hlevnjak, B., Hazic, V., Szabó, Z., Racskó, J., Holb. I., Nyéki, J. (2006): Fruit bearing shoot characteristics of apricot and sweet cherry cultivars in Hungary. Internat. J. Hortic. Sci. 12(2): 107-110.

Thurzó S, Szabó Z, Nyéki J, Racskó J, Drén G, Szabó T, Nagy J, Holb I, Veres Zs (2008): Some fruit-bearing shoot characteristic of nine sweet cherry cultivars in Hungary. Acta Hortic. 795:673-676.

Vaszily, B., Gonda, I. (2010): Training and maintaning spindle crown in cherry production. Internat. J. Hortic. Sci. 16(3): 5153.

Waterman, P. (2005): Cherry production trends in British Columbia. Acta Hortic. 667: 311-317.

Zahn, F. G. (1996): Close planting in relation to low orchard height. Hortic. Sci. 28 (1-2): 58-66. 